\title{
既製コンクリート杭の復元力特性に関する研究 RESTORING FORCE MODEL FOR PREFABRICATED CONCRETE PILES
}

\author{
池菩大輔*, 酒向 裕司**, 岡野 創*** \\ Daisuke IKEZAKI, Yuji SAKO and Hajime OKANO
}

\begin{abstract}
This paper presents the experimental data to improve the ductility of SC and PRC piles under the earthquake and the evaluation method of restoring force model for those piles. The parameter of the experiment is with or without infilled concrete. Infilled concrete improves the ductility of pile under the cyclic loading and with constant axial load. The relationships between shear force and drift angle evaluated by the fiber model analysis agree well with those experiments.
\end{abstract}

\section{Keywords : Prefabricated ConcretePiles, Ductility, Infilled Concrete, Restoring ForceMode, PileHead Connection, Fiber Modd Analysis 既製コンクリート杭，変形性能，中詰めコンクリート，復元力特性，杭頭接合部，断面解析}

\section{1. はじめに}

中低層建築物の杭基礎には, 工期短縮や排土量削減等の観点から, コスト・施工性に優位な既製コンクリート杭が採用される傾向にあ る。近年では, さらなる杭体耐力の向上および施工性の向上のため, 杭体に高強度材料を使用した高支持力杭も開発され，数多く適用さ れている。既製コンクリート杭は遠心成形により製作されるため中 空部材であり変形性能に乏しいが，基礎構造は許容応力度設計のみ が法的に義務付けられているのみであり，設計時に変形に関する検 討がなされない。このため, 二次設計やそれ以上の地震時外力に対 する杭基礎の余力が不十分であると考えられる。実際に, 2011 年東 日本大震災において杭基礎の破損による建物の沈下や傾斜が発生し ており, 被害のあった建物に使用されている杭種は全て既製コンク リート杭(PC 杭，PHC 杭)であったとの報告 2)がある。また, PHC 杭と比較して変形性能を有寸るとされている $\mathrm{SC}$ 杭(外殼鋼管付きコ ンクリート杭)や PRC 杭(遠心力プレストレスト鉄筋コンクリート 杭)については，地震による被害報告はないが，既往研究例えば 3,4)に より, 最大耐力直後にコンクリートの圧壊によって急激に耐力低下 に至ることが報告されている。

既製コンクリート杭の杭体自体の変形性能に関する既往研究とし ては, PHC 杭を対象とした黒正・和田らの研究 5)や PRC 杭を対象 とした長江・岸田らの研究 6)などがある。いずれの研究においても 中空部に中詰めコンクリートを充填することにより，脆性的な破壊 を抑止し変形性能が向上寸ることが示されている。しかし，これら の研究の杭体に用いられているコンクリート設計基準強度 Fc は $85 \mathrm{~N} / \mathrm{mm}^{2}$ 程度であり, 更に高強度化された杭体 $\left(\mathrm{Fc}=105 \mathrm{~N} / \mathrm{mm}^{2}\right.$ 級
など)に対して, 中詰めコンクリート充填による変形性能向上の効果 がどの程度発揮されるかは不明である。また, カバーコンクリート は損傷, 圧壊するので大地震後の継続使用性についての課題もある。 さらに, 杭頭部に用いられることが最も多い SC 杭の変形性能に関 する研究はほとんどなく, 近年部材実験が実施例えば,7)され始めてい るが, その変形性能は定量的に評価されていない。

一方で, 既製コンクリート杭に関する既往の部材実験についての 課題も少なくない。文献 3)でも示されているように, 単純梁試験で は, 曲げモーメント最大区間では純曲げ状態となり, 地震時の杭頭 部付近の応力が模擬されていない。地震時の杭頭部付近の応力を模 擬した部材実験方法としては, 片持ち梁形式による載荷方法がある。 しかし，杭頭接合部を模擬した黒正・和田らの研究を除き，ほとん どの既往研究が(1)杭体をスタブ内に杭径以上埋め込み完全固定を仮 定した部材実験 4),6),7)など，もしくは(2)杭頭補強筋を模擬するが杭体 の耐力よりも杭頭接合部の耐力が小さく設計された部材実験 8)などで あり，杭頭接合部を含む杭体の変形性能を確認できていない。

そこで本論文では，杭頭部に用いられることの多い SC 杭，PRC 杭を対象として, 以下に示寸検討を実施し, SC 杭, PRC 杭の復元 力特性の評価手法を提案する。

i ）杭頭接合部を含む既製コンクリート杭の部材実験の実施 (中詰めコンクリート充填による変形性能向上効果検証実験)

ii ）断面解析を用いた既製コンクリート杭の復元力特性評価手法 の提案と部材実験シミュレーション解析による評価精度検証 なお，本論文は日本建築学会大会学術講演 1)において発表した内 容に新たな分析結果を加え，作成したものである。

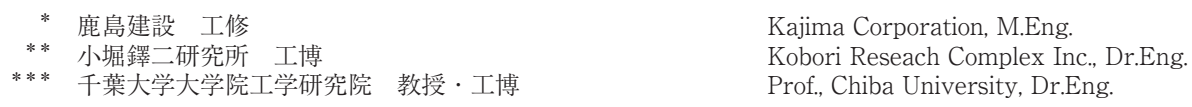




\section{2. 杭頭接合部を含む既製コンクリート杭の部材実験}

\section{1. 既製コンクリート杭の変形性能向上案}

Fig. 1 に SC 杭, Fig. 2 に PRC 杭の変形性能向上案を示す。

SC 杭（Fig.1）については，遠心成形により成形された従来製品 の中空部に, 中詰めコンクリートを充填するのみである。中詰めコ ンクリートが充填されることで，外殼鋼管の拘束効果が有効に発揮 されることを意図している。

PRC 杭 (Fig.2) については, 従来製品の杭体端部の使用材料等 のディテールとの連続性に配慮しつつ, 合理的に変形性能を向上さ れるようにディテールを改良している。一般的な従来製品の杭体端 部では，杭体コンクリート内の主筋が負担する応力を，コンクリー トの付着力によって, 端板と溶接によって接続された補強バンドと 呼ばれる鋼管に伝達している。

これに対して本論文の改良 PRC 杭では, 補強バンド設置区間内 で, 主筋及び PC 鋼棒の降伏による塑性ヒンジが形成されるように, 端板と補強バンド間に隙間を設けている。これによって，補強バン ドが曲げモーメントに抵抗せず, 拘束効果のみ有効となる。さらに, 中詰めコンクリートを充填し, 補強バンドの拘束効果が有効に発揮 されることで, 変形性能の向上を図っている。なお，より拘束効果 が得られるように, 補強バンドの鋼管厚さ及び鋼管長さを従来製品 よりも増大させている。また, 主筋の負担応力は, 端板と主筋を溶 接することで，直接端板に伝達できるようにしている。

なお, 中詰めコンクリート充填の際に, 杭体側コンクリート表面 にはスライム除去のため洗浄などの特別な処理は施さない。

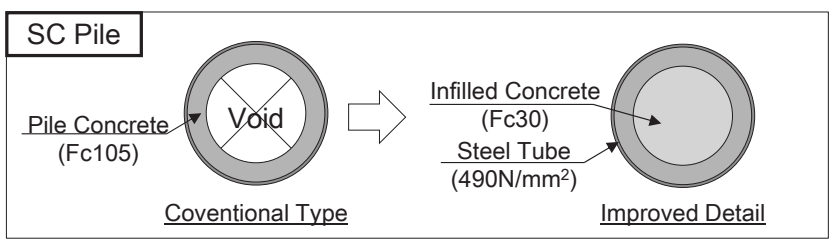

Fig.1 Detail to Improve the Ductility of SC Pile

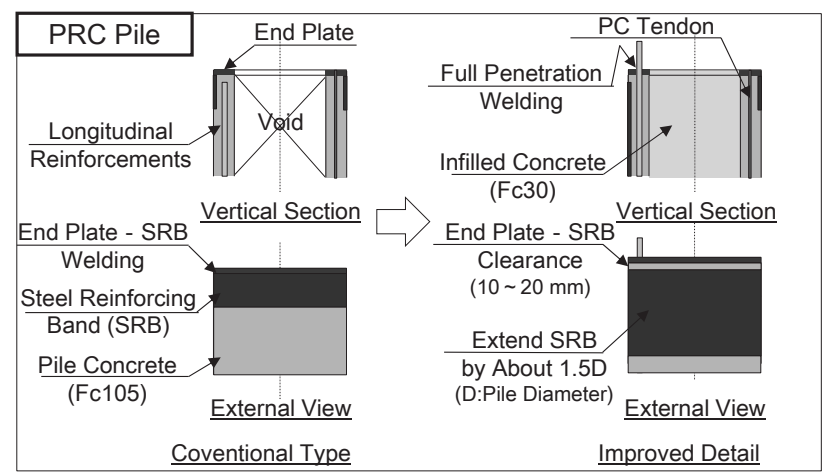

Fig.2 Detail to Improve the Ductility of PRC Pile

\section{2. 実験概要}

\subsection{1. 試験体概要}

Fig. 3 に試験体形状, Table1 に試験体一覧, Table2 に鋼材の材料 特性一覧, Table3 にコンクリートの材料特性一覧を示す。試験体は 実大の $1 / 3$ スケールとし外径 $400 \mathrm{~mm}$, 杭体 $\mathrm{PC}$ 部肉厚 $50 \mathrm{~mm}$, せ ん断スパンは地震力を受ける杭体の曲げモーメント分布において,
地中部曲げモーメントがゼロとなる深さまでを模擬することを意図

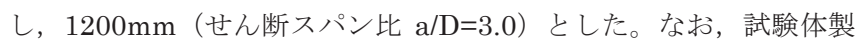
作にあたっては, 実施工時と同様の条件となるように, 杭体の上部 にスタブ（基礎フーチング）を配置した状態にてコンクリート打設 し, 加力時に上下反転させ反曲点位置にピン支承を設けた。載荷軸 力は短期圧縮側軸力（軸圧比 $0.2 \sim 0.3$ 程度）を想定し, 鉛直ジャッ キの載荷可能最大軸力 $\mathrm{N}=2000 \mathrm{kN}$ 一定とした。なお, Table1 に示 す軸力には初期プレストレスカは算入しない。使用する材料の強度 は一般の製品と同じとし，杭体 $\mathrm{PC}$ 部は Fc105N/mm², SC 杭の鋼 管は $490 \mathrm{~N} / \mathrm{mm}^{2}$ 級とした。改良 PRC の補強バンドは, 拘束効果を 期待するために, 一般の製品と比較して, 強度および鋼管厚さを増 大させており， $490 \mathrm{~N} / \mathrm{mm}^{2}$ 級，厚さ $6 \mathrm{~mm}$ とした。スタブおよび中 詰めコンクリートは, 基礎フーチングと同程度の強度を意図して $\mathrm{Fc} 30 \mathrm{~N} / \mathrm{mm}^{2}$ とし, 試験区間全長に亘って充填した。杭頭部は実施 工での実績が多い, 杭頭補強筋による鉄筋定着方式とし, 杭体終局 耐力の 1.2 倍程度の余裕度を有する配筋量とした。なお, 杭頭補強 筋の定着長は鉄筋径の 40 倍 $\left(40 \mathrm{~d}_{\mathrm{b}}\right)$ とした。
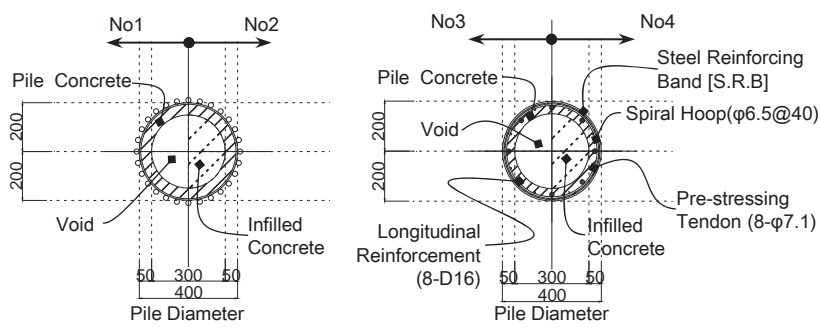

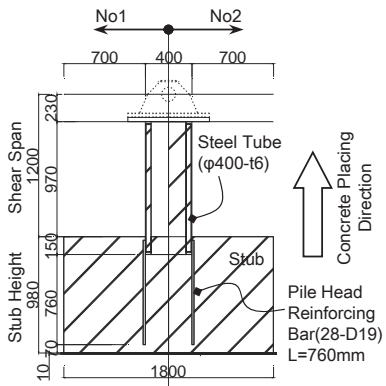

(a) SC Pile [No1,No2]

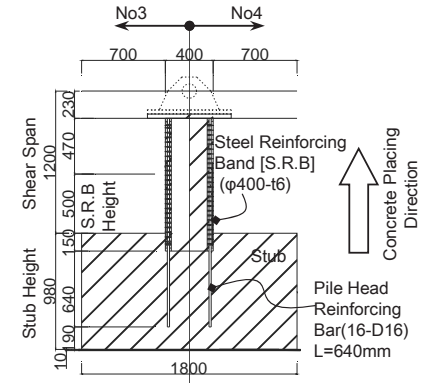

(b) PRC Pile [No3,No4]
Fig.3 Horizontal and Vertical Sectional View of Specimens

Table1 Details of Specimens

\begin{tabular}{|c|c|c|c|c|c|c|c|}
\hline \multirow[t]{2}{*}{ No. } & $\begin{array}{c}\text { Pile } \\
\text { Diameter }\end{array}$ & $\begin{array}{l}\text { Shear } \\
\text { Span }\end{array}$ & \multirow[t]{2}{*}{ Type } & $\begin{array}{l}\text { Axial } \\
\text { Load } \\
{[\mathrm{N}]^{* 1}}\end{array}$ & \multirow{2}{*}{$\begin{array}{c}\text { Axial } \\
\text { Force } \\
\text { ratio } \\
{[\mathrm{N} / \mathrm{Nu}]^{* 1}}\end{array}$} & \multirow[t]{2}{*}{$\begin{array}{l}\text { Infilled } \\
\text { Concrete }\end{array}$} & $\begin{array}{c}\text { Effective } \\
\text { Prestress } \\
{\left[\sigma \sigma^{\circ}\right]^{* 1}}\end{array}$ \\
\hline & $(\mathrm{mm}) * 2$ & $(\mathrm{~mm}) * 2$ & & $(\mathrm{kN}) * 2$ & & & $\left(\mathrm{~N} / \mathrm{mm}^{2}\right)^{* 2}$ \\
\hline 1 & \multirow{4}{*}{400} & \multirow{4}{*}{1200} & \multirow{2}{*}{$\mathrm{SC}$} & \multirow{4}{*}{2000} & 0.238 & Without & - \\
\hline 2 & & & & & 0.249 & Filling & - \\
\hline 3 & & & \multirow{2}{*}{ PRC } & & 0.310 & Without & 4.5 \\
\hline 4 & & & & & 0.307 & Filling & 4.5 \\
\hline
\end{tabular}

*1:[] shows the variable name , ${ }^{*} 2:()$ shows the unit $\mathrm{Nu}={ }_{\mathrm{SA}} \mathrm{A} \times{ }_{\mathrm{S}} \sigma_{\mathrm{y}}+{ }_{\mathrm{C}} \mathrm{A} \times \times_{\mathrm{C} \sigma} \sigma_{\mathrm{B}}$

SA : Sectional Area of Steel in Longitudinal Direction (Without SRB) cA : Sectional Area of Concrete 
Table2 Material Properties of Steel

\begin{tabular}{|c|c|c|c|c|c|c|}
\hline \multirow[t]{2}{*}{$\begin{array}{l}\text { Pile } \\
\text { Type }\end{array}$} & \multirow{2}{*}{\multicolumn{2}{|c|}{ Steel Type }} & $\begin{array}{c}\text { Yield } \\
\text { Strength } \\
{\left[\begin{array}{ll}\sigma & \mathrm{y}\end{array}\right]^{* 1}}\end{array}$ & $\begin{array}{c}\text { Elastic } \\
\text { Modulus } \\
{[\mathrm{Es}]^{* 1}}\end{array}$ & $\begin{array}{l}\text { Yield } \\
\text { strain } \\
{\left[\begin{array}{ll}\varepsilon & \mathrm{y}\end{array}\right]^{* 1}}\end{array}$ & $\begin{array}{c}\text { Tensile } \\
\text { Strength } \\
{\left[\begin{array}{ll}\sigma & \mathrm{u}\end{array}\right]^{* 1}}\end{array}$ \\
\hline & & & $\left(\mathrm{N} / \mathrm{mm}^{2}\right)^{2} * 2$ & $\left(\mathrm{~N} / \mathrm{mm}^{2}\right) * 2$ & $(\%) * 2$ & $\left(\mathrm{~N} / \mathrm{mm}^{2}\right) * 2$ \\
\hline \multirow{2}{*}{$\mathrm{SC}$} & $\begin{array}{l}\text { Steel } \\
\text { Tube }\end{array}$ & $\begin{array}{c}\text { t6 } \\
\text { (SKK490) }\end{array}$ & 385 & $2.05 \times 10^{5}$ & 0.188 & 588 \\
\hline & $\begin{array}{c}\text { Pile Head } \\
\text { Reinforcing } \\
\text { Bar }\end{array}$ & $\begin{array}{c}\text { D19 } \\
(\mathrm{SD} 490)\end{array}$ & 534 & $2.05 \times 10^{5}$ & 0.260 & 726 \\
\hline \multirow{5}{*}{ PRC } & $\begin{array}{c}\text { Steel } \\
\text { Reinforcing } \\
\text { Band (SRB) }\end{array}$ & $\begin{array}{c}\mathrm{t} 6 \\
(\mathrm{SM} 490 \mathrm{~A})\end{array}$ & 437 & $2.05 \times 10^{5}$ & 0.213 & 574 \\
\hline & $\begin{array}{l}\text { Longitudinal } \\
\text { Reinforcement }\end{array}$ & $\begin{array}{c}\text { D16 } \\
\text { (SD345) }\end{array}$ & 394 & $2.05 \times 10^{5}$ & 0.192 & 553 \\
\hline & $\begin{array}{l}\text { Pre-Stressing } \\
\text { (PS) Tendon }\end{array}$ & $\begin{array}{c}\phi 7.1 \\
\text { (SBPDL } \\
1275 / 1420 \text { ) } \\
\end{array}$ & 1477 & $2.05 \times 10^{5}$ & 0.939 & 1496 \\
\hline & Spiral Hoop & $\begin{array}{c}\phi 6.5 \\
(\mathrm{SD} 490)\end{array}$ & 618 & $2.05 \times 10^{5}$ & 0.473 & 642 \\
\hline & $\begin{array}{c}\text { Pile Head } \\
\text { Reinforcing } \\
\text { Bar }\end{array}$ & $\begin{array}{c}\text { D16 } \\
\text { (SD345) }\end{array}$ & 403 & $2.05 \times 10^{5}$ & 0.197 & 598 \\
\hline
\end{tabular}

*1:[ ] shows the variable name , ${ }^{* 2}$ ( ) shows the unit

Table3 Material Properties of Concrete

\begin{tabular}{|c|c|c|c|c|c|}
\hline \multirow[t]{2}{*}{$\begin{array}{c}\text { Location } \\
\text { of } \\
\text { Use }\end{array}$} & $\begin{array}{c}\text { Design } \\
\text { Strength } \\
{[\mathrm{Fc}]^{* 1}}\end{array}$ & \multirow[t]{2}{*}{ No. } & $\begin{array}{c}\text { Compressive } \\
\text { Strength } \\
{\left[\begin{array}{ll}\sigma & 0\end{array}\right]^{* 1}}\end{array}$ & $\begin{array}{c}\text { Strain at } \\
\text { Compressive } \\
\text { Strength } \\
{\left[\varepsilon_{0}\right]^{* 1}}\end{array}$ & $\begin{array}{l}\text { Elastic } \\
\text { Modulus } \\
{[\mathrm{Ec}]^{* 1}}\end{array}$ \\
\hline & $\left(\mathrm{N} / \mathrm{mm}^{2}\right)^{* 2}$ & & $\left(\mathrm{~N} / \mathrm{mm}^{2}\right)^{* 2}$ & $(\%) * 2$ & $\left(\mathrm{~N} / \mathrm{mm}^{2}\right)^{* 2}$ \\
\hline \multirow{4}{*}{$\begin{array}{c}\text { Pile } \\
\text { Concrete }\end{array}$} & \multirow{4}{*}{105} & 1 & 116.3 & 0.275 & $4.81 \times 10^{4}$ \\
\hline & & 2 & 109.1 & 0.272 & $4.52 \times 10^{4}$ \\
\hline & & 3 & 110.4 & 0.280 & $4.52 \times 10^{4}$ \\
\hline & & 4 & 111.9 & 0.267 & $4.80 \times 10^{4}$ \\
\hline \multirow{4}{*}{$\begin{array}{c}\text { Infilled } \\
\text { Concrete } \\
\& \\
\text { Stub } \\
\text { Concrete }\end{array}$} & \multirow{4}{*}{30} & 1 & 45.2 & 0.214 & $3.17 \times 10^{4}$ \\
\hline & & 2 & 50.4 & 0.239 & $2.99 \times 10^{4}$ \\
\hline & & 3 & 43.9 & 0.232 & $2.83 \times 10^{4}$ \\
\hline & & 4 & 44.0 & 0.241 & $2.52 \times 10^{4}$ \\
\hline
\end{tabular}

${ }^{*} 1:\left[\right.$ ] shows the variable name $,{ }^{*} 2:()$ shows the unit

\subsection{2. 加力及び計測方法}

Fig. 4 に試験体装置図, Fig.5 に変位計取付位置図を示す。試験体 はスタブ天端から反力床に設置した $\mathrm{PC}$ 鋼棒(8- $\phi 32$ B 種 1 号)に, 材料強度の $85 \%$ のプレストレスカを導入することによって固定し た。 PC 鋼棒によってスタブを反力床に緊結することで，杭頭接合 部回転変形には, 水平載荷中にスタブの回転が含まれず, 杭頭補強 筋の抜出し, もしくは杭体のスタブへの押し込みによる変形となる ようにした。加力は軸力 $\mathrm{N}=2000 \mathrm{kN}$ を一定に保持し，正負交番繰 り返し漸増載荷とした。水平力は加力ビームを水平に保つようにし て載荷した。なお，水平力は載荷ジャッキに取り付けたロードセル の值から鋁直ジャッキの傾斜による分力を差し引いた值とした。加 カサイクルは, ピン支承位置の水平変位 $\delta$ をん断スパン $1200 \mathrm{~mm}$ で除した值(部材角 $R$ )により制御し， $R= \pm 1 / 400 \mathrm{rad}$ を 1 サイクル, その後 $R= \pm 1 / 200 \mathrm{rad}, \pm 1 / 100 \mathrm{rad}, \pm 1 / 67 \mathrm{rad}, \pm 1 / 50 \mathrm{rad}, \pm$ $1 / 33 \mathrm{rad}, \pm 1 / 25 \mathrm{rad}, \pm 1 / 20 \mathrm{rad}$ 各 2 サイクルとした。

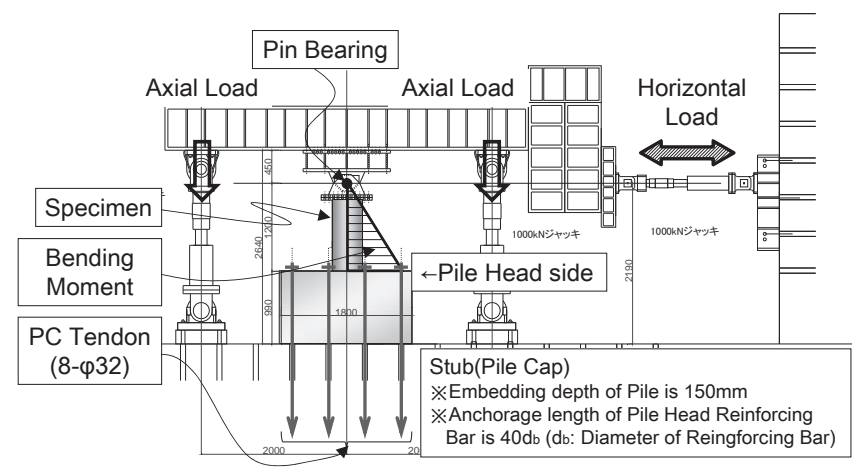

Fig.4 Loading Apparatus

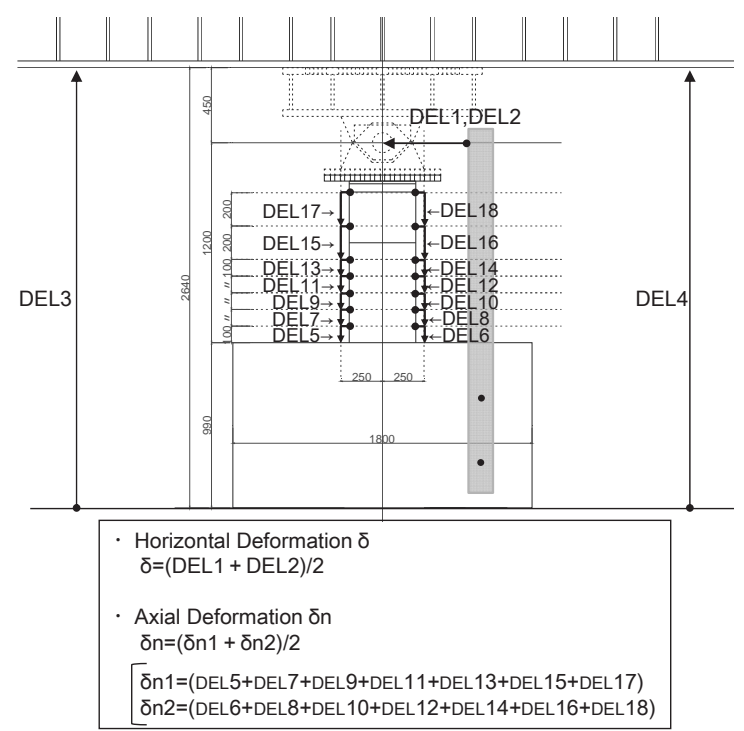

Fig. 5 Apparatus for Measurement of Deformation

\section{3. 実験結果}

\subsection{1. 荷重変形関係及び破壊性状}

Fig.6 に各試験体のせん断力 $Q$-相対変位 $\delta$ 関係, Fig.7 に各試験 体の水平変位 $\delta$-軸方向変位 $\delta_{n}$ 関係, Photo 1 に各試験体最終破壊 状況, Photo2 に No.1 試験体の中空部内破壊状況, Photo3 に危険 断面近傍の各試験体最終破壊状況を示す。なお本論では, Fig.7の 軸方向変位は, Fig. 5 に示すように杭体軸方向に取付した変位計の 值のうち, 圧縮側と引張側のそれぞれの累積值の平均值とした。ま た，限界変形角 $R_{u}$ を最大耐力の $90 \%$ に耐力低下した点とした。

（1） SC 杭：中詰めコンクリート有無比較（No.1, No.2）（Fig.6(a)） 中詰めコンクリート無し試験体 No.1 は, $R=1 / 100 \mathrm{rad}$ で最大耐力 に達した直後に急激に耐力低下に至った。中空部内に設置したビデ オカメラの映像をキャプチャーした Photo2 より, 急激に耐力低下 する瞬間のコンクリートの圧壊が確認された。鋼管の局部座屈の進 展は軽微であるため, 中詰めコンクリート無しの場合は, コンクリ ートの圧壊により脆性破壞に至ったと判断できる。また，Fig.7(a) より耐力低下に至った $R= \pm 1 / 100 \mathrm{rad} （ \delta= \pm 12 \mathrm{~mm}$ ）にて軸方向変 形が急激に縮む方向に進展したが，せん断力負担能力を喪失する $R=1 / 33 \mathrm{rad}$ 加力終了時まで所定軸力 $N=2000 \mathrm{kN}$ を保持していた。

中詰めコンクリート有り試験体 No.2 は， $R=1 / 67 \mathrm{rad}$ で最大耐力 に達した後は, 危険断面 $+50 \mathrm{~mm}$ 位置に局部座屈が確認されたが, 
急激な耐力低下なく $R=1 / 33 \mathrm{rad}$ まで最大耐力の $90 \%$ を維持した。 その後, $R=1 / 25 \mathrm{rad}$ にて鋼管の引張側に延性亀裂が発生し, $R=1 / 13 \mathrm{rad}$ にて当該部分の鋼管破断によって耐力低下に至った。軸 力は, 加力終了時まで所定軸力 $N=2000 \mathrm{kN}$ を保持していた。

(2) PRC 杭: 中詰めコンクリート有無比較 (No.3, No.4) (Fig.6(b)) 中詰めコンクリート無し試験体 No.3 は， $R=1 / 67 \mathrm{rad}$ で最大耐力 に達した後, $R=1 / 50 \mathrm{rad}$ 一回目のサイクル中に, $R=1 / 75 \mathrm{rad}$ で補強 バンドとの境界部にてコンクリートの圧壊とともに主筋座屈が生じ, 急激に耐力低下に至った (Photo1 参照)。また, Fig.7(b)より耐力 低下時に, 軸方向変形が急激に縮む方向に進展している。 SC 杭と は異なり，耐力低下とともに軸力保持性能も哐失した。

中詰めコンクリート有り試験体 No.4 は， $R=1 / 50 \mathrm{rad}$ で最大耐力 に達した後, 補強バンドの境界部のカバーコンクリートの損傷及び 杭頭部周りのスタブ上面のコンクリートの剥離が確認されたが, $R=1 / 25 \mathrm{rad}$ まで最大耐力の $90 \%$ を維持した。その後, 危険断面十 $50 \mathrm{~mm}$ 位置に局部座屈が確認(Photo3)されたが， $R=1 / 10 \mathrm{rad}$ まで安 定した履歴性状を維持し, 加力終了時まで所定軸力 $N=2000 \mathrm{kN}$ を 保持していた。

$\mathrm{SC}$ 杭，PRC 杭ともに，中詰めコンクリート無しの場合は，コン クリートの圧壊により急激に耐力低下に至った。一方で，中詰めコ ンクリート有りの場合は, SC 杭は鋼管, PRC 杭は端板と絶縁され た補強バンドの拘束効果により, コンクリートの圧壊による急激な 耐力低下が抑止され，変形性能が向上した。また，補強バンドとの 境界部にて破壊に至った No.3 試験体を除き, Photo3 より鋼管およ び補強バンドの局部座屈は危険断面位置+50mm 位置にて確認され た。SC 杭中詰めコンクリート無し試験体 No.1 のコンクリート圧壊 位置も同程度であることから，中詰めコンクリートの有無に関わら ず，外殼鋼管を有する杭体は，危険断面位置+50mm 位置まで鋼管 およびスタブによって拘束されていると考えられる。

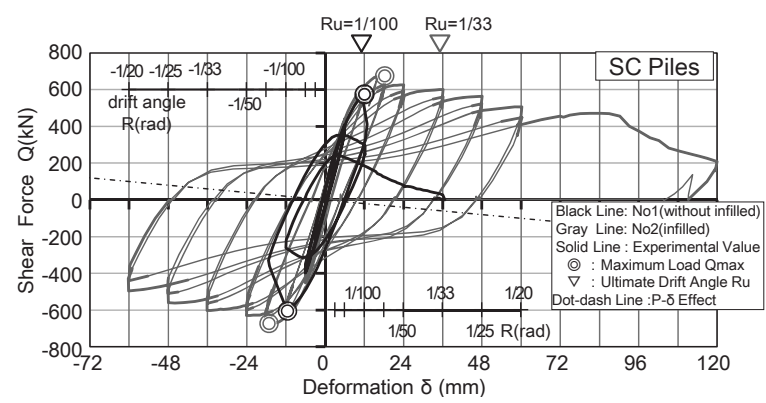

(a) SC Piles (Specimen No.1 and No.2)

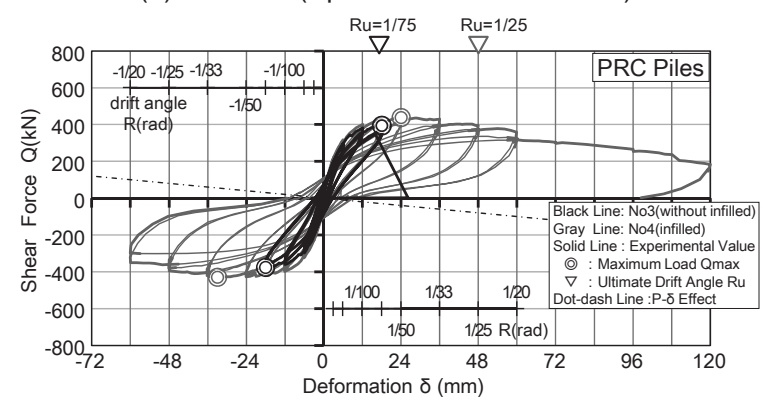

(b) PRC Piles (Specimen No.3 and No.4)

Fig.6 Shear Force - Horizontal Deformation Relationship

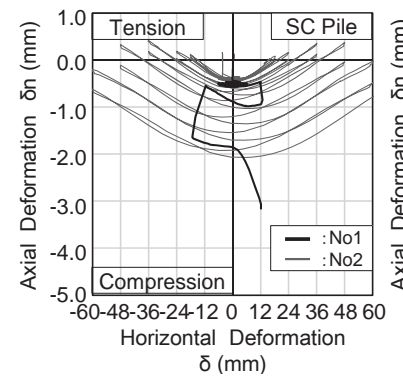

(a) SC Piles

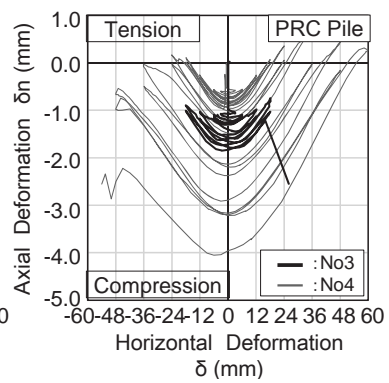

(b) PRC Piles
Fig.7 Axial Deformation - Horizontal Deformation Relationship

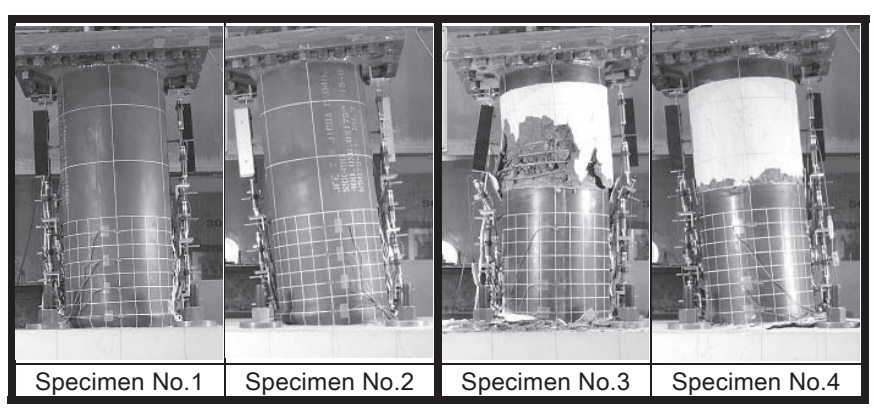

Photo1 Ultimate Conditions (after Loading)

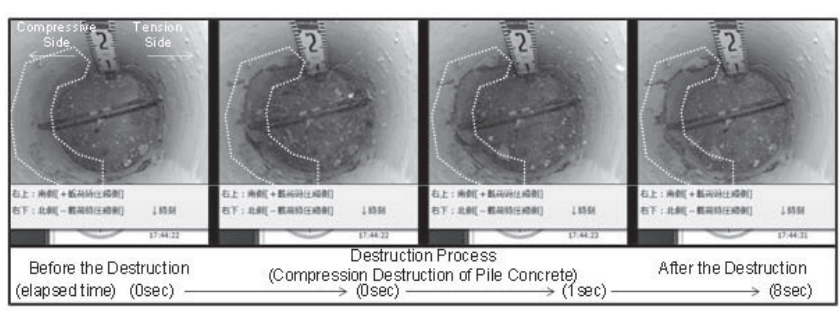

Photo2 Destruction Process of SC Pile without Infilled Concrete (Specimen No1: Capturing the moving images at $R=-1 / 100$ rad)

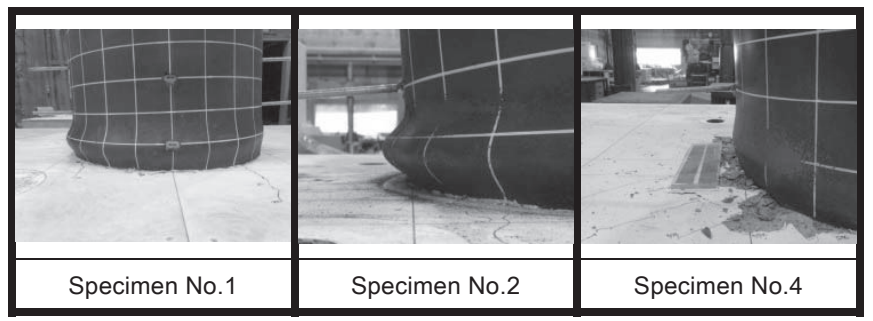

Photo3 Ultimate Conditions in the Vicinity of Stub Top

\subsection{2. 歪性状}

(1)SC 杭

Fig.8にNo.1 試験体の最大耐力時の加力サイクルにおける鋼管の 鉛直歪度の推移を示す。

Fig.8 より, 中詰めコンクリート無し試験体 No.1 について, 局部 座屈の生じた危険断面 $+50 \mathrm{~mm}$ の鋼管圧縮側の鋼管表面と裏面に貼 付けした歪ゲージの值の平均值による鉛直歪の推移を確認すると, 最大耐力に到達する以前に, 材料試験の杭体コンクリートの圧縮強 度時の歪度に到達している。また, 杭体が最大耐力に到達し圧壊に 至る時点では，鋼管の拘束効果を考慮して計算された拘束コンクリ 
一トの圧縮強度時の歪度の計算值程度まで到達している。なお, 拘 束コンクリートの圧縮強度時の歪度は, 3.1 .1 に示寸(3)〜(6)式によ って算出している。このことから, 中詰めコンクリートがない場合 においても，鋼管の拘束効果によって，コンクリートの圧縮強度時 の歪度及びコンクリートの圧縮強度が増大していると考えられる。
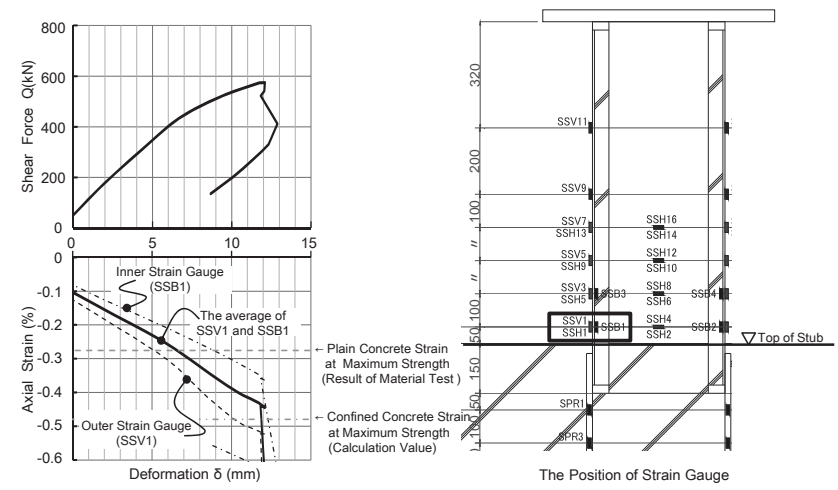

Fig.8 Axial Strain Transition at Maximum Loading Cycle (No.1)

\section{(2)PRC 杭}

Fig.9 に補強バンド鉛直歪分布, Fig.10にNo.3 試験体の耐力低下 時サイクルの PC 鋼棒の歪ゲージの值による鉛直歪度の推移を示す。

補強バンドは曲げモーメントを負担しないように端板と絶縁した が，Fig.9より, 補強バンドの圧縮側の歪度については, 中詰めコ ンクリートの有無によらず, 圧縮降伏歪を超過している。この要因 としては，絶縁した隙間部にコンクリートが充填されており，かつ 補強バンドがスタブ内に埋め込まれているので, 補強バンド小口部 分から圧縮力が伝達されたためと考えられる。なお，補強バンド引 張側については，計画通り引張力を負担しないことが確認できる。

また Fig.10より，中詰めコンクリート無し試験体 No.3 について は, SC 杭の中詰めコンクリート無し試験体 No.1 と同様に, 最大耐 力に到達する以前に危険断面位置の $\mathrm{PC}$ 鋼棒の圧縮歪が，材料試験 結果の杭体コンクリートの圧縮強度時の歪度に到達している。一方 で，破壊に至った補強バンド境界部近傍の $\mathrm{PC}$ 鋼棒の圧縮歪が，杭 体コンクリートの圧縮強度時の歪に到達すると同時に最大耐力とな り，急激に耐力低下に至っている。さらに，破壊位置が補強バンド 境界部となった現象とも合致している。このことから $\mathrm{SC}$ 杭と同様 に，中詰めコンクリートがない場合においても，補強バンド設置区 間内では補強バンドの拘束効果により，コンクリートの圧縮強度時 の歪度及びコンクリートの圧縮強度が増大していると考えられる。 (a) Specimen No.3

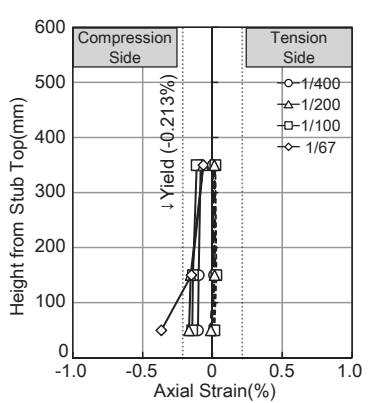

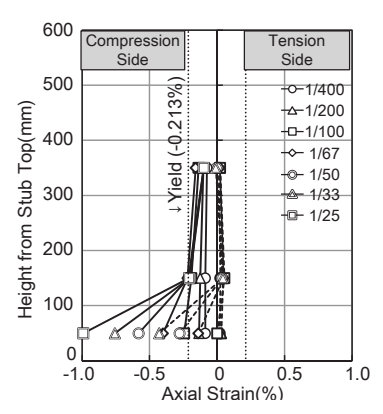

(b) Specimen No.4
Fig. 9 Axial Strain of Steel Reinforcing Band

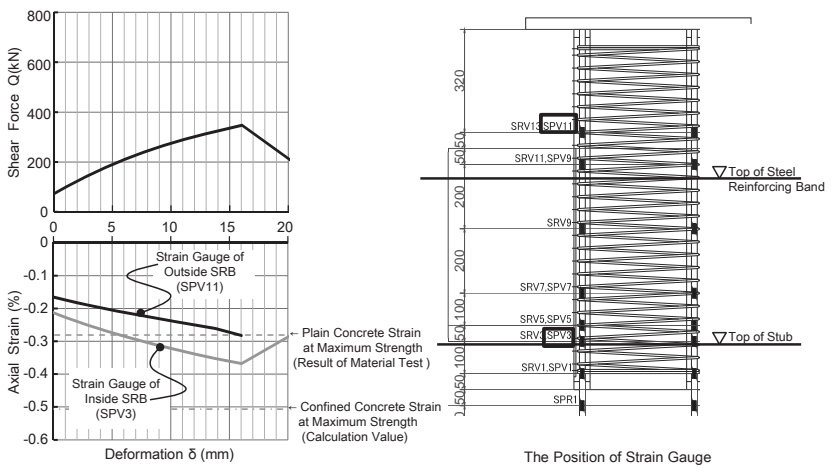

Fig.10 Axial Strain Transition at Maximum Loading Cycle (No.3)

\section{4. 部材実験のまとめ}

中空部の中詰めコンクリート有無を変動要因とした, 杭頭接合部 を含む $\mathrm{SC}$ 杭および改良 PRC 杭の部材実験により以下の知見を得た。

(1) SC 杭及び改良 PRC 杭いずれの場合も, 中空部に中詰めコンク リートを充填することにより, コンクリートの圧壊による脆性 破壊を抑止でき，変形性能が向上する。

(2) 中詰めコンクリートがない場合, SC 杭についてはせん断力負 担能力を喪失しても軸力保持性能は有しているが, PRC 杭に ついてはコンクリートの圧壊により軸力保持性能も喪失する。

（3) 一方で，中詰めコンクリートがない場合においても，鋼管およ び改良補強バンドによる拘束効果により, コンクリート圧縮強 度および圧縮強度時の歪度は増大する。ただし, 圧縮勒性の向 上は見込めない。

(4)改良補強バンドについては, 絶縁部の隙間のコンクリート充填 および杭体のスタブ内埋め込みにより圧縮側のみ曲げモーメ ントによる応力を負担する。

\section{3. 断面解析を用いた既製コンクリート杭の復元力特性評価手法}

\section{1. 解析概要}

\subsection{1. 曲げ耐力算定方法}

Fig.11 に断面解析に用いた応力度 $(\sigma)$ 一歪度 $(\varepsilon)$ 関係を示す。 曲げ耐力は平面保持仮定の断面解析により算出し, 材料の各要素 に使用する $\sigma-\varepsilon$ 関係は以下に示寸通り設定した。

(a)コンクリート

圧縮側のコンクリートの $\sigma-\mathcal{E}$ 関係は，(1)式，(2)式に示す Fafitis-Shah 式 9)によって評価する。2.3.2 にて述べたように鋼管内 のコンクリートについては, 材料試験によるコンクリートの圧縮強 度時の歪度を超過しても耐力低下に至らなかったため, 外殼鋼管を 有する $\mathrm{SC}$ 杭および改良 PRC 杭のコンクリート要素には, 中詰めコ ンクリートの有無に関わらず，鋼管等の拘束効果による圧縮強度お よび圧縮強度時歪の増大を考慮する。拘束効果を考慮したコンクリ 一トの圧縮強度時の歪度 $\varepsilon$ coは(3)式によって算出し, 圧縮強度上昇 率 $K$ は，外殼鋼管の有無によって(5)式，(6)式によって算出する。 中詰めコンクリートの有無による圧縮靭性の差異については, 軟化 係数 $k$ によって考慮する。中詰めコンクリートがある場合は Fig.11(a)に示すように, 孫-崎野式 14)で評価される $\sigma-\varepsilon$ 関係と同等 になるように設定し, 中詰めコンクリートがない場合は, Fafitis-Shah ${ }^{9)}$ の原式を用いる。引張側のコンクリートの $\sigma-\mathcal{E}$ 関係 
は出雲式 10)によって評価し, 軟化性状を表す係数は 0.4 とした。

圧縮強度まで $\sigma=K \sigma_{B} \times\left\{1-\left(1-\varepsilon / \varepsilon_{c 0}\right)^{\alpha}\right\}$

圧縮強度以降 $\sigma=K \sigma_{B} \times \exp \left\{-k\left(\varepsilon-\varepsilon_{c 0}\right)^{1.15}\right\}$

$$
\text { ここで, } \alpha=E_{c} /\left(\sigma_{B} / \varepsilon_{c 0}\right)
$$

$\varepsilon_{c 0}$ : 拘束コンクリートの圧縮強度時の歪度で(3)式による。

$$
\varepsilon_{c 0}=\varepsilon_{0} \begin{cases}1+4.7(K-1), & K \leq 1.5 \\ 3.35+20(K-1.5), & K>1.5\end{cases}
$$

$\varepsilon_{0}:$ プレーンコンクリートの圧縮強度時の歪度で(4)式による。

$\varepsilon_{0}=0.5243 \cdot\left(\sigma_{B}\right)^{\frac{1}{4}} \times 10^{-3}$

$E_{c}:$ コンクリートのヤング係数 $\left(\mathrm{kgf} / \mathrm{cm}^{2}\right)$

\section{$k$ : コンクリートの圧縮強度以降の軟化係数}

中詰めコンクリートがある場合：孫-崎野式同等に設定

中詰めコンクリートがない場合 : $k=2.42 \sigma_{B}$

$\sigma_{B}$ : プレーンコンクリートの圧縮強度 $\left(\mathrm{kgf} / \mathrm{cm}^{2}\right)$

$K \sigma_{B}$ : 拘束効果による強度上昇を考慮したコンクリート

の圧縮強度 $\left(\mathrm{kgf} / \mathrm{cm}^{2}\right)$ で(5)式，(6)式による

（杭体の外凯に鋼管がある場合 : SC 杭，改良 PRC 杭）

$$
\begin{aligned}
& K \sigma_{B}=\sigma_{B}+ 0.3 \times 4 \times\left(2 \times t /{ }_{c} D\right) \times{ }_{s} \sigma_{y} \\
& \text { ここで, } t: \text { 鋼管厚さ }(\mathrm{cm}) \\
&{ }_{c} D: \text { 鋼管の外径 }(\mathrm{cm}) \\
&{ }_{s} \sigma_{y}: \text { 鋼管の降伏強度 }\left(\mathrm{kgf} / \mathrm{cm}^{2}\right)
\end{aligned}
$$

（杭体の外殼に鋼管がない場合 : PRC 杭）

$$
\begin{aligned}
& K \sigma_{B}=\sigma_{B}+ 2.09\left(1-s /\left(2 \times D_{c}\right)\right)^{2} \times \rho_{s} \times \sigma_{y} \\
& \text { ここで, } s: \text { 横補強笳ピッチ }(\mathrm{cm}) \\
& D_{c}: \text { 横補強筋に囲まれる部分の径 }(\mathrm{cm}) \\
& \rho_{s}: \text { 横補強筋体積比 } \\
& \sigma_{y}: \text { 横補強筋の降伏強度 }\left(\mathrm{kgf} / \mathrm{cm}^{2}\right)
\end{aligned}
$$

(b)鋼管および PRC 主筋

鋼管および $\mathrm{PRC}$ 主筋の $\sigma-\varepsilon$ 関係は, 材料試験結果による降伏強 度を折れ点とするバイリニアとする。降伏後剛性は初期剛性の 1/100 とする。(Fig.11(b))

(c) $\mathrm{PC}$ 鋼棒

$\mathrm{PC}$ 鋼棒についても鋼管等と同様に材料試験結果による降伏点剛 性を折れ点とするバイリニアとするが，プレストレスによる引張応

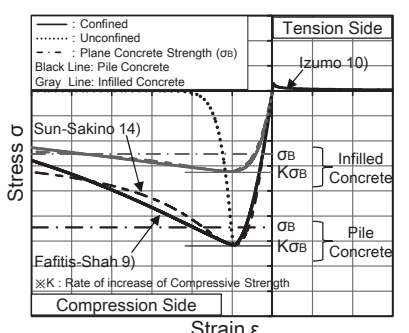

(a) Concrete

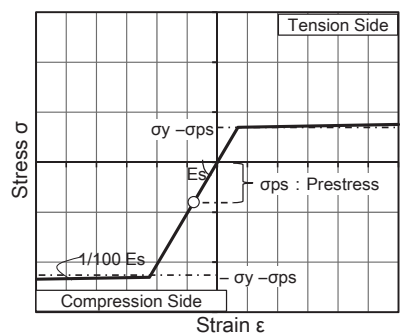

(c) PC Tendon
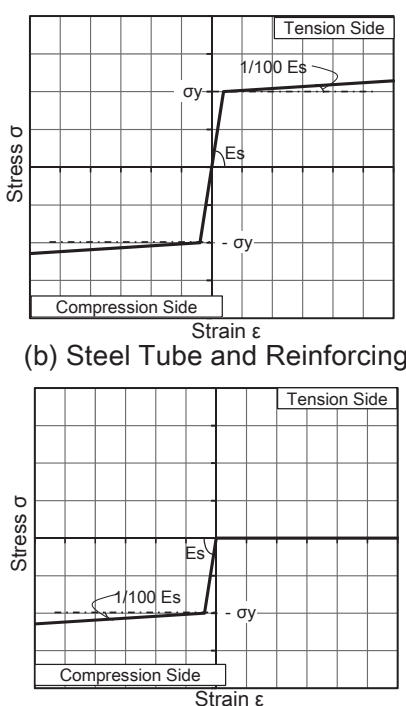

(d) Steel Reinforcing Band (b) Steel Tube and Reinforcing

Fig.11 Stress-Strain Relationship for Fiber Analysis

カ分オフセットさせて設定する。(Fig.11(c))

(d)補強バンド（改良 PRC 杭のみ）

Fig.9 より, 改良 PRC 杭における補強バンドは, 引張側では抵抗 しないが圧縮側では通常の鋼材と同様の挙動をすると考えられるの で，圧縮側のみ有効となる $\sigma-\varepsilon$ 関係を設定する。(Fig.11(d))

\subsection{2. 変形量算定方法}

(1)仮定条件

一般的に杭基礎は曲げ変形が支配的であると考えられるが，杭頭 部では接合部からの抜け出し,もしくは押し込みによる回転変形(以 下, 接合部回転変形) や, せん断スパン比が小さくせん断変形が無 視できない場合があると考えられる。そこで本研究では, 杭体の変 形は(1)曲げ変形 $\left(\delta_{b}\right)$ (2)せん断変形 $\left(\delta_{s}\right)$ (3)接合部回転変形 $\left(\delta_{r}\right)$ の和として評価する。

(2)各変形成分の算定方法

Fig.12 に解析モデルを示す。

Photo3 にて確認された通り, 鋼管・補強バンド等の外殼鋼管を有 する場合には，それらとスタブの拘束によって，コンクリートの圧 壞位置がスタブ天端 $+50 \mathrm{~mm}$ となっていることから, それらの杭体 については当該区間に剛域を設定する。

$(2-1)$ 曲げ変形 $\left(\delta_{b}\right)$

曲げ変形は, Fig. 12 に示すように材軸方向に $0.5 \mathrm{D}$ (D : 杭径)程度

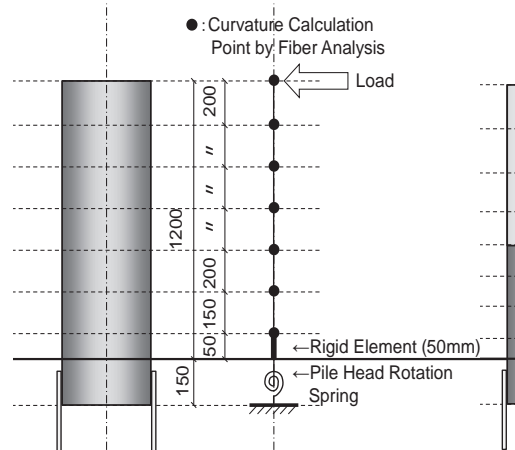

(a) SC Pile (with Anchorage Bar)

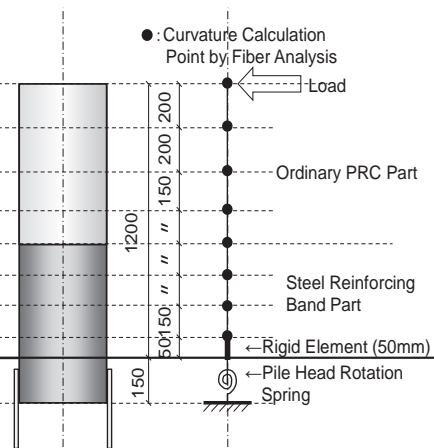

(b) Improvement PRC Pile (with Anchorage Bar)

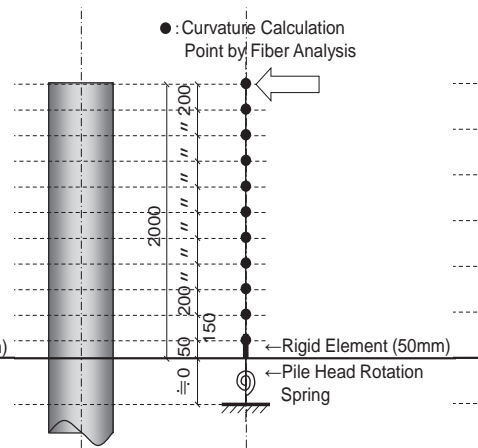

(c) SC Pile

(without Anchorage Bar)

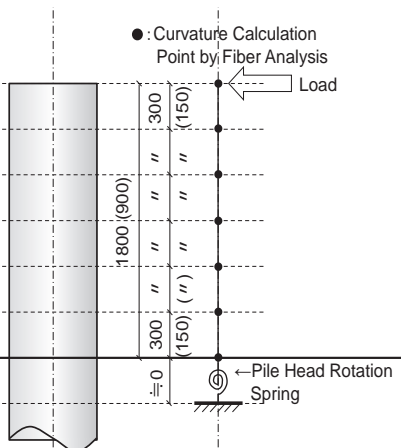

(d) PRC Pile

(without Anchorage Bar)

Fig.12 Analysis Model 
ごとに設けた曲率計算位置において, 負担曲げモーメントに対応し た曲率を算出する。曲率計算位置の中間部は線形と仮定して曲率分 布を設定し，得られた曲率分布から曲げ変形を算出する。

$(2-2)$ せん断変形 $\left(\delta_{s}\right)$

せん断変形は弾性と仮定し，(7)式により算出する。せん断断面積 As は各材料のヤング係数比を考慮した等価な全断面積 Ae に対して 以下のように設定する。

$$
\delta s=Q /\left(\mathrm{G}_{\mathrm{c}} \times \mathrm{A}_{\mathrm{s}}\right) \times \mathrm{L}
$$

ここで, 中詰なし $\mathrm{As}_{\mathrm{s}}=\mathrm{Ae} / 2$, 中詰あり $\mathrm{As}_{\mathrm{s}}=\mathrm{Ae}_{\mathrm{e}} /(4 / 3)$

$$
Q \text { : せん断力, Gc : 杭体コンクリートせん断弾性係数 }
$$

$(2-3)$ 接合部回転変形 $\left(\delta_{r}\right)$

(2-3-1)杭頭補強筋接合タイプ[Fig.12(a)(b)]（本論文実験検討用）

Fig.13 に杭頭接合部の仮想円形断面及び仮定した杭頭補強筋の 歪分布, Fig.14 に等価定着長実験值 $\exp L_{d}$ の設定方法概念及び杭頭 補強筋の引張歪実験值 $($ exp $\varepsilon s t)$ - 等価定着長実験值の無次元化量 $\left(\right.$ exp $\left.L_{d} / \mathrm{d}_{\mathrm{b}}\right)$ 関係を示す。なお, $\mathrm{d}_{\mathrm{b}}$ は杭頭補強筋径とする。

$\mathrm{SC}$ 杭の杭頭接合部に関する既往の研究 8 により, 杭頭補強筋の歪 は平面保持であること, 接合部の耐力は杭径 $+20 \mathrm{~cm}$ の仮想コンクリ 一ト円柱を想定して算定することで実験值とよく一致することが示 されている。そこで, 本論においても Fig.13 に示寸仮想円形断面を 用いた断面解析により，杭頭接合部位置での曲げモーメント $M$ 一曲 率 $\phi_{r}$ 関係を算出する。接合部回転変形は，杭頭補強筋の歪分布を Fig.13 に示すような三角形分布と仮定し, 次のように算出する。 なお，各式の記号は Fig.13 中に示す。

$$
\begin{aligned}
& R_{r}=1 / 2 \times \varphi_{r} \times{ }_{c a l} L_{d} \\
& \delta_{r}=R_{r} \times\left(L+L^{\prime}\right)
\end{aligned}
$$

等価定着長 $c a l L_{d}$ は, 文献 11)に示されている以下の(10)式の定着 鉄筋の付着長さ算定式により算出する。

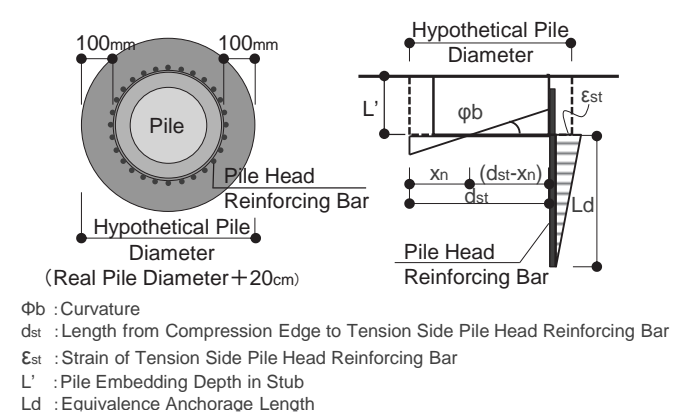

Fig.13 Imaginary Circular Section of Pile Head for Fiber Analysis and Assumed Strain Distribution of Pile Head Reinforcing Bar
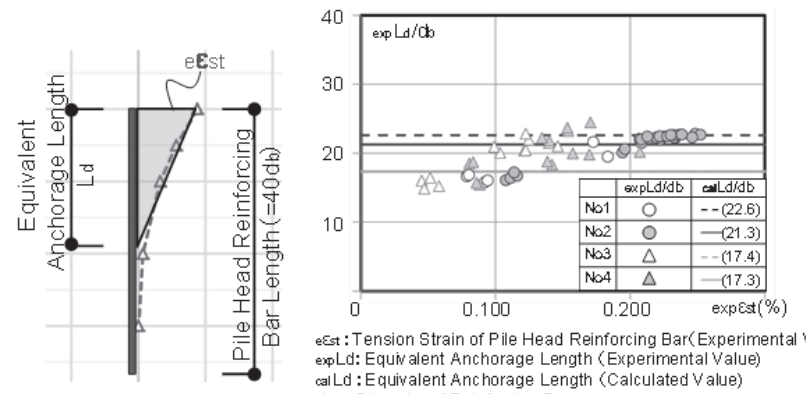

est: Tension Strain of Pile Head Reinforcing Bar(Experimental Value expLd: Equivalent Anchorage Length (Experimental Value) cal Ld: Equivalent Anchorage Length (Calculated Value)

Fig.14 Equivalent Anchorage Length and exp $\varepsilon_{t}-\exp L d / d_{b}$ Relationship

$$
{ }_{c a l} L_{d}=\lambda \cdot \alpha \cdot \frac{s \cdot \sigma_{y} \cdot d b}{10 \cdot f_{b}}
$$

(符号) $f_{b}$ : 付着割裂の規準となる強度 $f_{b}=F_{c} / 40+0.9 \quad\left(\mathrm{~N} / \mathrm{mm}^{2}\right)$

$\lambda:$ 付着長さの補正係数で, $\lambda=0.86$ とする

$\alpha$ : 割裂破壊に対する補正係数で， $\alpha=1.0$ (コア内定着)

$S:$ 必要長さの修正係数で, 直線定着する定着鉄筋の場合 1.0

\begin{tabular}{|c|c|c|c|c|c|c|c|c|c|c|c|c|c|}
\hline \multirow[b]{2}{*}{$\begin{array}{l}\text { Specimen } \\
\text { No. }\end{array}$} & \multirow[b]{2}{*}{$\begin{array}{c}\text { Pile } \\
\text { Diameter } \\
(\mathrm{mm})\end{array}$} & \multirow[b]{2}{*}{$\begin{array}{l}\text { Shear } \\
\text { Span } \\
{[\mathrm{a} / \mathrm{D}]} \\
(\mathrm{mm})\end{array}$} & \multirow[b]{2}{*}{ Type } & \multirow[b]{2}{*}{$\begin{array}{c}\text { Axial } \\
\text { Load } \\
{[\mathrm{N}]} \\
(\mathrm{kN})\end{array}$} & \multirow[b]{2}{*}{$\begin{array}{l}\text { Infilled } \\
\text { Concrete }\end{array}$} & \multirow[b]{2}{*}{$\begin{array}{l}\text { Pile Head } \\
\text { Joint Type }\end{array}$} & \multicolumn{3}{|c|}{ Pile Concrete } & \multicolumn{3}{|c|}{ Infilled Concrete } & \multirow[b]{2}{*}{$\begin{array}{c}\text { Pile Head } \\
\text { Rotation } \\
\text { Spring } \\
{[\mathrm{Kr}]} \\
(\mathrm{kNm} / \mathrm{rad})\end{array}$} \\
\hline & & & & & & & $\begin{array}{l}\text { Strain of } \\
\text { Confined } \\
\text { Concrete } \\
{\left[\varepsilon c_{0}(\%)\right]}\end{array}$ & \begin{tabular}{|c|} 
Rate of \\
Increase \\
of Strength \\
{$[\mathrm{K}]$}
\end{tabular} & $\begin{array}{c}\text { Softening } \\
\text { Coefficient } \\
{[k]}\end{array}$ & $\begin{array}{l}\text { Strain of } \\
\text { Confined } \\
\text { Concrete } \\
{\left[\varepsilon c_{0}(\%)\right]}\end{array}$ & $\begin{array}{c}\text { Rate of } \\
\text { Increase } \\
\text { of Strength } \\
{[\mathrm{K}]}\end{array}$ & $\begin{array}{c}\text { Softening } \\
\text { Coefficient } \\
{[k]}\end{array}$ & \\
\hline 1 & \multirow{4}{*}{400} & \multirow{4}{*}{$\begin{array}{l}1200 \\
{[3.0]}\end{array}$} & \multirow{2}{*}{$\mathrm{SC}$} & \multirow{4}{*}{2000} & Without & \multirow{4}{*}{$\begin{array}{c}\text { With } \\
\text { Anchorage } \\
\text { Bar }\end{array}$} & 0.480 & 1.12 & 1980 & - & - & - & $1.060 \times 10^{6}$ \\
\hline 2 & & & & & Filling & & 0.488 & 1.13 & 55 & 0.572 & 1.28 & 25 & $1.077 \times 10^{6}$ \\
\hline 3 & & & \multirow{2}{*}{$\begin{array}{c}\text { Improvement } \\
\text { PRC }\end{array}$} & & Without & & 0.496 & 1.14 & 1880 & - & - & - & $7.749 \times 10^{5}$ \\
\hline 4 & & & & & Filling & & 0.495 & 1.14 & 50 & 0.650 & 1.36 & 20 & $7.749 \times 10^{5}$ \\
\hline CU_No.17) & \multirow{3}{*}{400} & \multirow{3}{*}{$\begin{array}{l}2000 \\
{[5.0]}\end{array}$} & \multirow{3}{*}{$\mathrm{SC}$} & 1250 & Without & \multirow{3}{*}{$\begin{array}{c}\text { Without } \\
\text { Anchorage } \\
\text { Bar }\end{array}$} & 0.505 & 1.14 & 1992 & - & - - & - & $9.314 \times 10^{4}$ \\
\hline CU_No. $2^{7)}$ & & & & 1250 & Fillinn & & 0.505 & 1.14 & 55 & 0.895 & 1.54 & 15 & \multirow{2}{*}{$1.226 \times 10^{5}$} \\
\hline CU_No.3 ${ }^{7)}$ & & & & 1875 & Filling & & 0.505 & 1.14 & 55 & 0.895 & 1.54 & 15 & \\
\hline $6 \mathrm{IV}-52-\mathrm{P}^{6)}$ & \multirow{3}{*}{600} & \multirow{3}{*}{$\begin{array}{l}1800 \\
{[3.0]}\end{array}$} & \multirow{3}{*}{ PRC } & \multirow{3}{*}{1372} & \multirow{3}{*}{ Filling } & \multirow{3}{*}{$\begin{array}{c}\text { Without } \\
\text { Anchorage } \\
\text { Bar } \\
\end{array}$} & 0.377 & 1.07 & 270 & 0.450 & 1.25 & 30 & \multirow{3}{*}{$6.162 \times 10^{5}$} \\
\hline $6 \mathrm{IV}-111-\mathrm{P}^{6)}$ & & & & & & & 0.471 & 1.13 & 85 & 0.777 & 1.52 & 20 & \\
\hline $6 \mathrm{IV}-177-\mathrm{P}^{6)}$ & & & & & & & 0.600 & 1.23 & 45 & 2.300 & 1.89 & 5 & \\
\hline $3 \mathrm{IV}-53-\mathrm{P}^{6)}$ & \multirow{9}{*}{300} & \multirow{9}{*}{$\begin{array}{c}900 \\
{[3.0]}\end{array}$} & \multirow{9}{*}{ PRC } & & & & 0.375 & 1.06 & 280 & 0.419 & 1.20 & 35 & \\
\hline $3 \mathrm{IV}-123-\mathrm{P}^{6)}$ & & & & 343 & & & 0.478 & 1.14 & 85 & 1.017 & 1.58 & 15 & \\
\hline $3 \mathrm{IV}-186-\mathrm{P}^{6)}$ & & & & & & & 0.575 & 1.21 & 50 & 1.390 & 1.65 & 10 & \\
\hline $3 I V-53-T^{6)}$ & & & & & & Without & 0.375 & 1.06 & 280 & 0.419 & 1.20 & 35 & \\
\hline $\left.3 \mathrm{IV}-123-\mathrm{T}^{6}\right)$ & & & & 687 & Filling & Anchorage & 0.478 & 1.14 & 85 & 1.017 & 1.58 & 15 & $7.702 \times 10^{4}$ \\
\hline $\left.3 \mathrm{IV}-186-\mathrm{T}^{6}\right)$ & & & & & & Bar & 0.575 & 1.21 & 50 & 1.390 & 1.65 & 10 & \\
\hline $3 \mathrm{IV}-53-\mathrm{U}^{6)}$ & & & & & & & 0.369 & 1.06 & 280 & 0.437 & 1.25 & 30 & \\
\hline $\left.3 I V-123-U^{6}\right)$ & & & & 980 & & & 0.478 & 1.14 & 85 & 1.017 & 1.58 & 15 & \\
\hline $3 \mathrm{IV}-186-\mathrm{U}^{6)}$ & & & & & & & 0.579 & 1.21 & 50 & 2.270 & 1.90 & 5 & \\
\hline
\end{tabular}

等価定着長実験值 exp $L_{d}$ は, 杭頭補強筋全長の歪の積分値と, 三角 形分布と仮定した場合の歪の積分值が等価となる長さとする。

Fig.14より, 杭頭補強筋歪 $\exp \varepsilon s_{s t}$ が大きいほど $\exp _{d} / \mathrm{d}_{\mathrm{b}}$ は大きくな

Table4 Details of Specimens 
る傾向を示しているが，平均的には(10)式で算出された等価定着長 計算值 $c a l L_{d}$ と同程度となっている。

(2-3-2)杭頭埋め込み接合タイプ[Fig.12(c)(d)]（既往実験検討用）

既製コンクリート杭の部材実験の多くは，スタブに杭体を埋め込

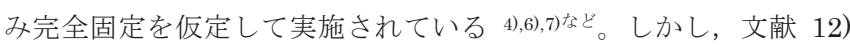
に示されているように，既往の実験により求められた固定度 $\alpha_{r}{ }^{12}$ は $\alpha_{r}=0.8 \sim 1.0$ 程度であり平均的には $\alpha_{r}=0.9$ と示されている。そ こで, 本論文では $\alpha_{r}=0.9$ と仮定し， $\alpha_{r}$ を求める式 13$)$ から導出した (11)式により算出した杭頭回転剛性 $K_{r}$ を Fig.12(c)(d)に示寸接合部 回転ばねとして設定する。

$$
\begin{aligned}
& K_{r}=\frac{M_{b}}{R_{b}}=\frac{\alpha_{r}}{\left(1-\alpha_{r}\right)} E I \frac{1}{2 h} \\
& \text { ここで, }
\end{aligned}
$$

$E, I:$ 杭体のコンクリートヤング係数, 断面二次モーメント $h$ : せん断スパン（片持ち形式の場合，試験区間長）

\section{2. 部材実験のシミュレーション解析}

\subsection{1. 解析対象試験体概要}

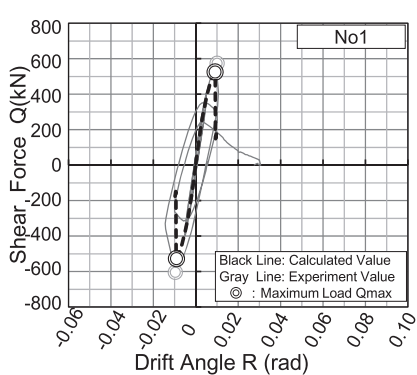

(a) No.1

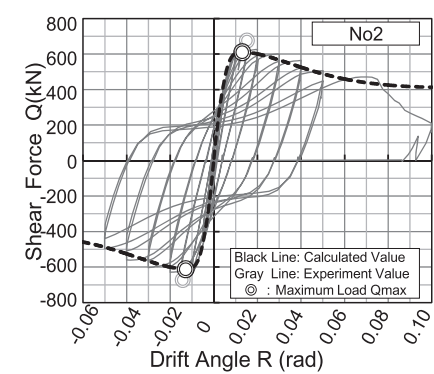

(b) No.2
Table4 に解析対象試験体詳細一覧を示寸。解析対象とした試験 体は, SC 杭 5 体, 改良 PRC 杭 2 体, PRC 杭 12 体の合計 19 体で ある。試験体のその他諸元については各論文を参照されたい。なお, SC 杭を対象とした文献 7)の試験体のうち CU_No.4については, 引 張軸力に対する抵抗機構等, 加力詳細が不明であるので解析対象か ら除いた。また, Table4には解析に用いた諸元を併せて示している が，No.1〜No.4 試験体の $K_{r}$ には，ひび割れ発生点と原点を結んだ 弾性剛性の值を示している。

\subsection{2. 解析結果}

\subsubsection{1 復元力特性評価結果}

本論文で実験を実施した試験体について, Fig.15 に復元力特性実 験值一計算值比較, Fig.16 に杭頭接合部の曲げモーメント $M$ 一接合 部回転角 $R_{r}$ 関係の実験值一計算値比較, Fig.17 に既往研究の代表 的な試験体の復元力特性実験值一計算值比較, Fig. 18 に全体変形に 対する各変形成分の割合推移を示す。Fig.15, Fig.17 の解析結果に は軸力による P- $\Delta$ 効果を考慮している。なお, Fig.17 には参考文献 中の図に本論文の解析結果を加筆している。また, Fig.16 の接合部

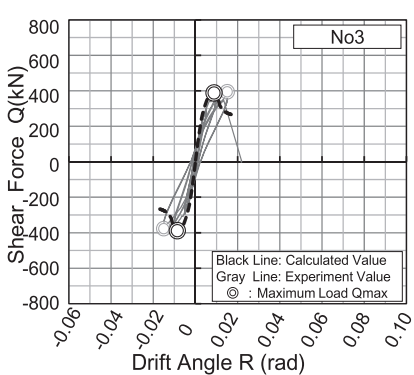

(c) No.3

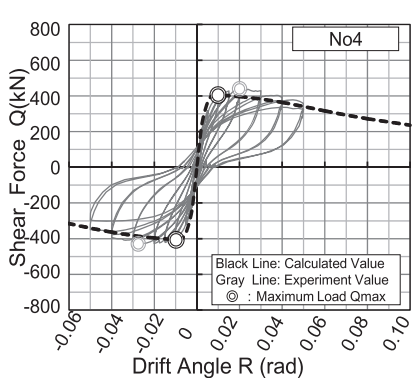

(d) No.4
Fig.15 Shear Force - Drift Angle Relationship (Experimental Data of this paper)

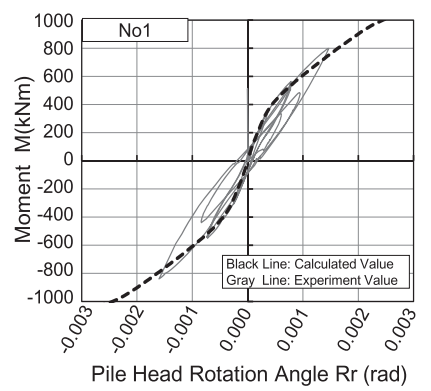

(a) No.1

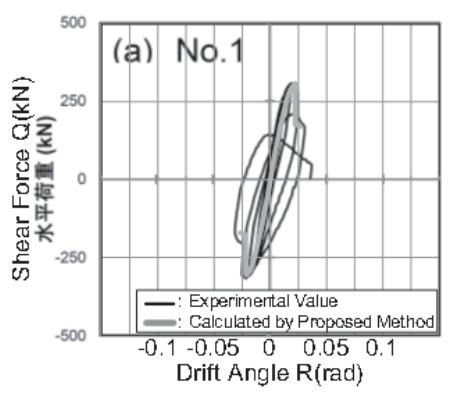

(a) CU_No.1

(Quote from Tsukakoshi ,2016)

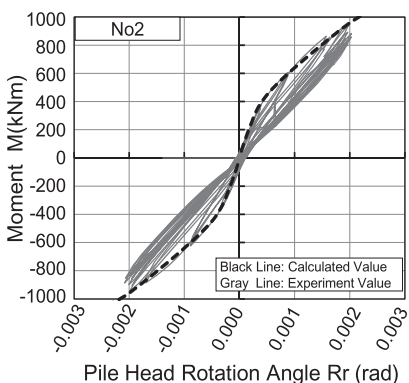

(b) No.2

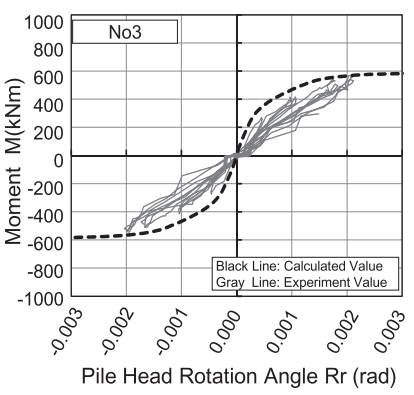

(c) No.3

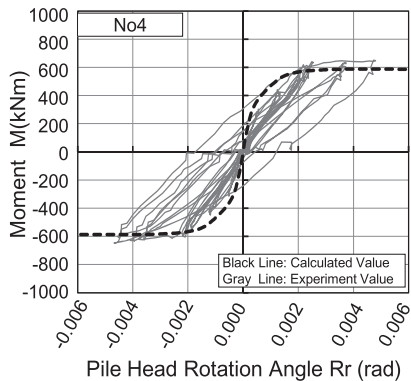

(d) No.4
Fig.16 Bending Moment - Pile Head Rotation Angle Relationship

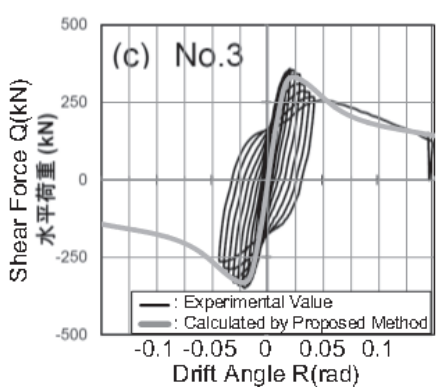

(b) CU_No.3

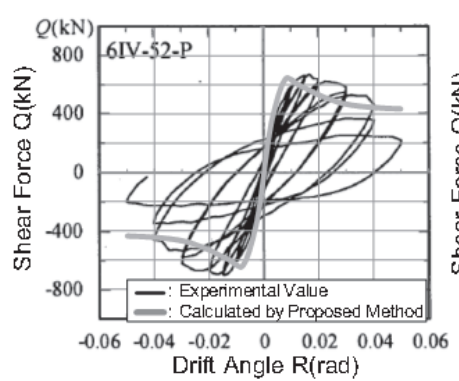

(c) 6IV-52-P
(Quote form Tsukakoshi ,2016)

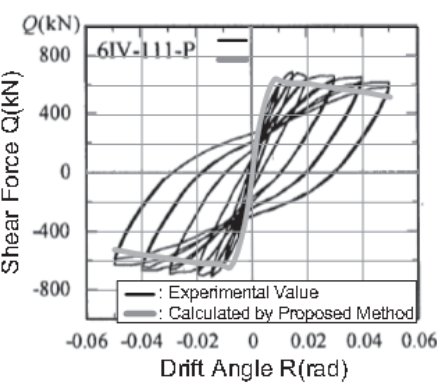

(d) 6IV-111-P

(Quote from Nagae ,2002)

Fig.17 Shear Force - Drift Angle Relationship (Previous Experimental Data) 


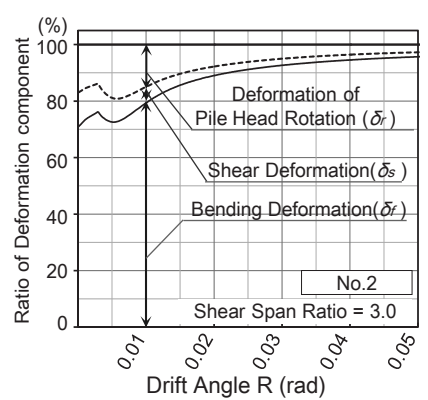

(a) No.2

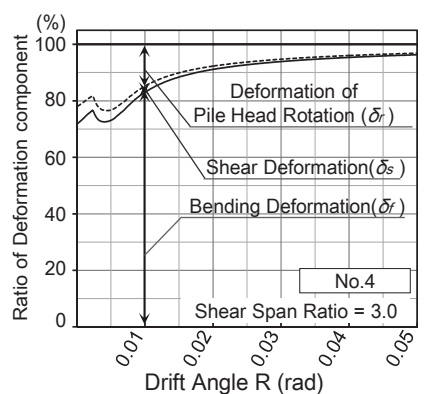

(b) No.4

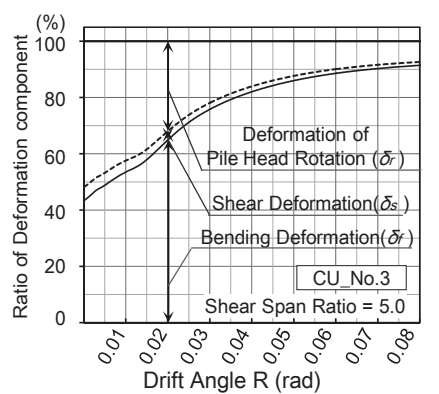

(c) CU_No.3

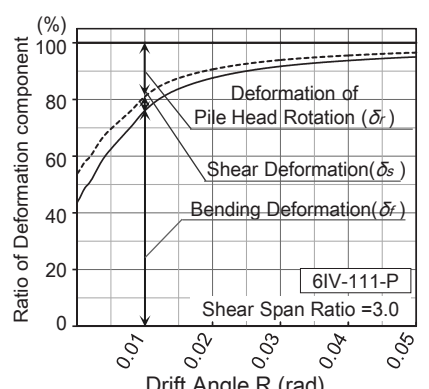

(d) 6IV-111-P

Fig.18 Transition of Deformation Component Ratio

回転角 $R_{r}$ 実験值は, 最外縁に位置する杭頭補強筋全長の歪の積分值 を伸縮量とし，それらの差分を圧縮側，引張側の杭頭補強筋間距離 で除した值とした。Fig.16 の計算值は 3.1.2 の(2-3)接合部回転変形 に示す仮想円形断面を用いた断面解析に基づく，杭頭接合部位置に おける $M-R_{r}$ 関係のみを評価した場合を示している。

まず，本論文で実験を実施した試験体について，実験結果を基に 条件を設定した 3.1 の評価手法を用いることで，Fig.15よりいずれ の試験体も, 初期剛性から最大耐力, 最大耐力後の劣化勾配まで復 元力特性実験值を精度よく評価することができている。杭頭接合部 の $M-R_{r}$ 関係について考察すると，Fig.16 より，いずれの試験体に おいても, 初期剛性から杭体の最大耐力に至るまで，杭頭接合部の $M-R_{r}$ 関係実験值を十分評価できている。なお，Fig.16 では計算值 耐力が実験值を超過しており SC 杭(Fig.16(a)(b))ではその傾向が顕 著であるが，上述したとおり Fig.16 の計算值は，杭頭接合部位置に おける $M-R_{r}$ 関係のみを評価した場合を示しており，それらの試験 体は杭頭接合部耐力に至る以前に, 杭体が最大耐力に至っているこ とが要因であるので, 評価に影響はないといえる。

次に, 載荷条件及び杭頭接合条件が本論文の試験体とは異なる既 往研究の試験体を対象に, 3.1 の評価手法の精度検証を試みる。

Fig.17より, 最大耐力以降の劣化性状の精度にばらつきがあるが, $\mathrm{SC}$ 杭，PRC 杭ともに概ね復元力特性実験值を評価できている。

各変形成分の割合を考察すると Fig.18より,いずれの試験体にお いても杭体曲げ変形成分 $\left(\delta_{f}\right)$ が支配的であり, 最大耐力時付近では $65 \%$ ～ $80 \%$ となっている。最大耐力以降は杭体の塑性化が進行する ことで， $\delta_{f}$ の割合は $90 \%$ 以上なる。せん断変形成分 $\left(\delta_{s}\right)$ は，そ の他の変形成分と比較すると割合は低いが，最大耐力時には $5 \%$ $10 \%$ 程度占めている。また, 接合部回転変形成分 $\left(\delta_{r}\right)$ については, 最大耐力以降の負担割合や推移は, 杭頭接合タイプによらずほぼ同 等である。一方, 最大耐力以前の変形レベルでは, 杭頭接合形式に よって負担割合及びその推移が異なっている。杭頭補強筋接合夕イ プにおいては， $R=0.025 \mathrm{rad}$ 近辺で接合部回転変形成分が一時的に 増大寸る現象が生じているが，接合部回転ばねが杭体自体に先行し て非線形化したためであると考えられる。 $R=0.05 \mathrm{rad}$ 以降では，杭 体の非線形化が進展し, 杭体曲げ変形成分が支配的になることが確 認できる。杭頭埋め込みタイプで，同様の現象が確認されない要因 としては， $\alpha_{r}=0.9$ 一定かつ弾性と設定し，非線形性を考慮してい ないことが挙げられるが，いずれの接合部形式においても，本論文 で検討した試験体では，杭体自体の変形が支配的であるので，接合 部回転ばねの影響は小さいと考えられる。

\subsubsection{2 最大耐力 $Q_{\text {max }}$ 及び限界変形角 $R_{u}$ 評価結果}

Fig.19 に解析対象全試験体の最大耐力実験值 $\left(\right.$ exp $\left.Q_{\max }\right)$ - 計算值 $\left.{ }_{(c a l} Q_{\max }\right)$ 比較, Fig.20 に限界変形角実験值 $\left(e_{\text {exp }} R_{u}\right)$ - 計算值 $\left({ }_{c a l} R_{u}\right)$ 比較 を示す。なお本論文において限界変形角 $R_{u}$ は, 実験と同様に最大 耐力の $90 \%$ に耐力低下した点とした。また, 論文中に ${ }_{\text {exp }} R_{u}$ が明記 されていない試験体については, 論文中の水平力 $Q$-部材角 $R$ 関係 から読み取った值を使用した。

Fig.19より最大耐力 $Q_{\text {max }}$ は，対象としたいずれの試験体におい ても実験值を精度よく評価している。Fig.20より限界変形角 $R_{u}$ は, 杭頭補強筋接合タイプの場合は, 精度よく評価できている。一方, 既往実験をシミュレーション解析した杭頭埋め込み接合タイプの場 合はややばらつきがみられ, 計算值は実験值を過小評価する傾向に ある。文献 13)には, 荷重が大きくなるにつれて, 固定度が低下し ていくことが示されている。本論文の評価では, 杭頭埋め込みタイ プの杭頭回転ばねを $\alpha_{r}=0.9$ 一定, かつ弾性としているため, 固定 度の低下による変形の増大を評価できず，ばらつきが生じたといえ る。固定度は施工状況によってばらつきが生じるので定量化には多 数の実験結果の分析が必要である ${ }^{13)}$ が，本評価結果は概ね安全側に 評価されていることから， $R_{u}$ の評価においては， $\alpha_{r}=0.9$ 一定とし て差し支えないといえる。

以上から, 本論文で提案している復元力特性評価手法は, 杭体種 別, 接合部形式に関わらず, 実験值を精度よく評価できるといえる。
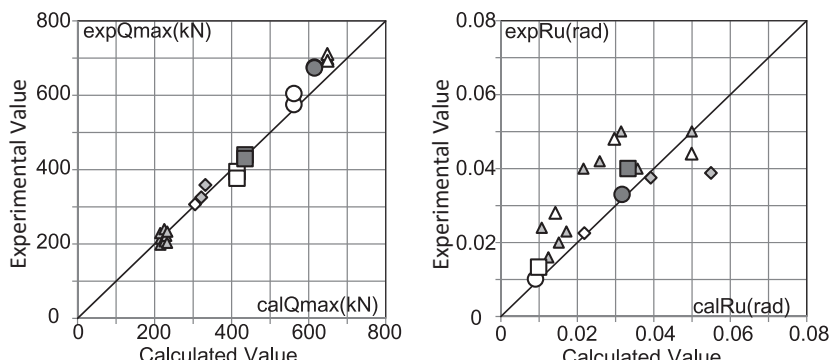

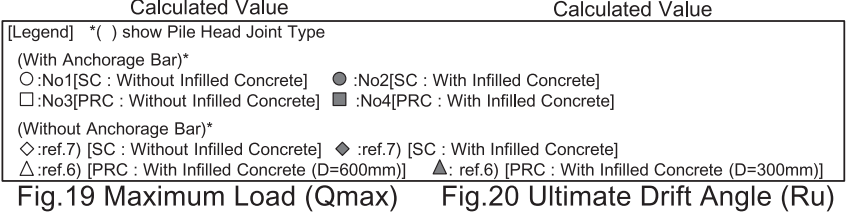

(Comparison between Experimental Value and Calculated Value)

\section{4. まとめ}

以下に本研究で得られた知見をまとめる。 
(1) 杭頭接合部を含む静的載荷実験により, SC 杭, 改良 PRC 杭と もに既製コンクリート杭の中空部に中詰めコンクリートを充 填することにより，コンクリートの圧壊による脆性破壊が抑止 され，変形性能が向上することを確認した。

(2) 中詰めコンクリートがない場合, SC 杭はせん断力負担能力を 喪失しても軸力保持性能は有していたが，改良 PRC 杭はコン クリートの圧壊により軸力保持性能も喪失した。

(3) 静的部材実験を基に解析条件を設定した断面解析に基づく復 元力特性評価手法を提案した。提案した評価手法は, 本論文中 の部材実験及び載荷条件等の異なる既往研究の部材実験結果 の復元力特性を精度よく評価できていた。

\section{謝辞}

実験遂行にあたっては, 横浜国立大学 田才晃教授, 杉本訓祥准教 授, 畠中雄一技官, 及び研究室学生諸兄には多大なるご助力・ご助 言頂きました。ここに記して厚く感謝の意を表します。

\section{参考文献}

1) Ikezaki,D. ,Okano,H. ,Sako,Y. ,Tasai,A. ,Sugimoto,K.and other 2 :Experimental Research on Ductility of Prefabricated Piles (Part1,Part2), Summaries of Technical Papers of Annual Meeting, Architectural Institute of Japan, Structures-I, pp.731-734, 2016.8(in Japanese)

池㟢大輔, 岡野創, 酒向裕司, 田才晃, 杉本訓祥ほか 2 名 : 既製杭( $\mathrm{SC}$ 杭・PRC 杭)の変形性能に関する実験的研究（その 1)（その 2), 日本建 築学会大会学術講演梗概集, 構造 I, pp.731-734,2016.8

2) Nakai, S. ,Kaneko, O. ,Abe, A. and Iiba, M.:A study on damage and its factor of pile foundations during the 2011 off the pacific coast of Tohoku earthquake (Part1), Summaries of Technical Papers of Annual Meeting, Architectural Institute of Japan, Structures-I, pp.695-696, 2014.9(in Japanese)

中井正一, 金子治, 阿部秋男, 飯場正紀 : 東北地方太平洋沖地震におけ る杭基礎被害の要因分析に向けた検討（その 1），日本建築学会大会学 術講演梗概集，構造 I , pp695-696,2014.9

3) Ogura, H. ,Tanaka, Y. ,Suga, K. ,Nakai, S. ,Sekiguchi, T. and Nakai, S.: Evaluation of $\mathrm{M}^{-} \varphi$ relationship of SC pile by simple beam method (Part1)(Part2),Summaries of Technical Papers of Annual Meeting, Architectural Institute of Japan, Structures-I, pp.429-432, 2015.9(in Japanese)

小椋仁志, 田中佑二郎, 菅一雅, 中井伸, 関口徹, 中井正一：単純梁方 式による SC 杭の M- $\varphi$ 関係の評価（その 1) (その 2), 日本建築学会大会 学術講演梗概集，構造 I , pp429-432,2015.9

4) Takemori, K. and Honma, Y. : Study on flexural deformation of precast concrete piles(Part3)(Part4) ,Summaries of Technical Papers of Annual Meeting, Architectural Institute of Japan, Structures-I, pp.761-764, 2016.8(in Japanese)

竹森敬介, 本間裕介 : 既製コンクリート杭の曲げ変形性能に関する研究 （その 3）（その 4）, 日本建築学会大会学術講演梗概集, 構造 I, pp761-764,2016.8

5) Kokusho, S. ,Wada, A. ,Kobayashi, K. ,Mitsugi, S. and Ueda, K. Experiments on the Seismic Behavior of PHC Piles, Journal of Structural and Construction Engineering, Architectural Institute of
Japan, No.376, pp.71-80, 1987.6(in Japanese)

黒正清治, 和田章, 小林克己, 光木史朗, 上田邦成: 軸力と水平力を受 ける高強度 PC 杭の力学的性状に関寸る実験, 日本建築学会構造系論文 報告集，第 376 号, pp.71-80,1987.6

6) Nagae, T. ,Kishida, S. ,Yanase, T. ,Katori, K and Hayashi, S.: Relationship between Earthquake Resistant Property and Amount of Lateral Reinforcement of PRC Pile, Journal of Structural and Construction Engineering, Architectural Institute of Japan, No.551, pp.95-102, 2002.1(in Japanese)

長江拓也, 岸田慎司, 柳瀬高仁, 香取慶一, 林静雄 : PRC 杭の耐震性能 と横補強筋量の関係, 日本建築学会構造系論文集, 第 551 号, pp.95-102,2002.1

7) Tsukagoshi, T. ,Nakai, S. ,Ogura, H. ,Nakai, S. ,Tanaka, Y. and other 3 : Evaluation of $\mathrm{M}-\varphi$ relationship of SC pile by the Cantilever Beam Method Bending Shear Test(Part1), Summaries of Technical Papers of Annual Meeting, Architectural Institute of Japan, Structures-I, pp.735-736, 2016.8(in Japanese)

塚越俊裕, 中井正一, 小椋仁志, 中井伸, 田中佑二郎ほか 3 名：片持ち 梁方式曲げせん断試験による $\mathrm{SC}$ 杭の $\mathrm{M}-\varphi$ 関係の評価（その 1）, 日本 建築学会大会学術講演梗概集, 構造 I, pp.735-736,2016.8

8) Kawai, H. ,Inada, O. ,Yamagishi ,M. ,Tsuduki, M. and other 2 : Experimental Study on the Joints of SC Pile and Footing(Part1) (Part2), Summaries of Technical Papers of Annual Meeting, Architectural Institute of Japan, Structures-I, pp.1551-1552, 1990.10(in Japanese)

川合弘之, 稲田修, 山岸勝, 都築充雄ほか 2 名 : SC 杭を使った杭頭接合 部に関する実験(その 1)(その 2), 日本建築学会大会学術講演梗概集.B, 構造 I , pp.1551- $1552,1990.9$

9) Fafitis,A. and Shah, S.P. :Lateral Reinforcement For High-Strength Concrete Columns, ACI Special Publication, No.SP-87(1985)

10) Izumo, J. ,Shima, H. , and Okamura ,H. : Analysis Model for Reinforced Concrete Panels to In-Plane Shear, Technical Papers of Japan Concrete Institute, pp.107-120, 1987.9(in Japanese) 出雲淳一, 島弘, 岡村甫 : 面内力を受ける鉄筋コンクリート板要素の解 析モデル，コンクリート工学, Vol.25,No9,pp.107-120,1987.9

11) Architectural Institute of Japan : AIJ Guidelines for Seismic Design of Reinforced Concrete Foundation Members (Draft), pp178-179,2017.3 日本建築学会 : 鉄筋コンクリート基礎構造部材の耐震設計指針(案)・同解 説,pp.178-179,2017.3

12) Architectural Institute of Japan : Recommendations for Design of Building foundations, pp323,2001.10 日本建築学会 : 建築基礎構造設計指針,pp.323,2001.10

13) Akiyama, H. ,Tanahashi, H. ,Kato ,M. and other 3 : Experimental Studies on the Steel Pipe Pile Footing Connections Under Lateral Forces(Part5), Summaries of Technical Papers of Annual Meeting, Architectural Institute of Japan, Structures-I, pp.1003-1004, 1985.10(in Japanese)

秋山宏, 棚橋秀光, 加藤征宏, ほか 3 名 : 水平力を受ける鋼管くい基礎 接合部に関する実験（その 5), 日本建築学会大会学術講演梗概集.B, 構 造 I , pp.1003- 1004,1985.10

14) Sakino, K. ,Sun, Y. : Experimental Studies on Axial Behavior Confined High-Strength Concrete, Technical Papers of JCI Annual Convention, Vol.15, No.2 pp.713-718, 1993(in Japanese) 崎野健治, 孫王平: コンファインド高強度コンクリートの中心軸圧縮性 状に関する実験的研究，コンクリート工学年次論文報告集, Vol.15, No.2 pp. 713 - 718,1993 


\title{
RESTORING FORCE MODEL FOR PREFABRICATED CONCRETE PILES
}

\author{
Daisuke IKEZAKI*, Yuji SAKO** and Hajime OKANO *** \\ * Kajima Corporation, M.Eng. \\ ** Kobori Reseach Complex Inc., Dr.Eng. \\ *** Prof., Chiba University, Dr.Eng.
}

This paper presents the experimental data to improve the ductility of prefabricated concrete piles under the earthquake and the suggestion of restoring force model for those piles.

Recently, prefabricated piles tend to be used for the pile foundation of medium and low storied buildings, because those piles are high workability and cost efficiency in comparison with cast-in-place concrete piles. On the other hand, the ductility of prefabricated piles are lower than cast-in-place concrete piles, because prefabricated piles are produced by centrifugal molding. However, the checking against deformation performance of building piles is unnecessary in the building standard law of Japan. Therefore, the ductility of piles is not enough, when the deformation becomes more excessive than assumed.

The second chapter shows the improved detail and the experiment result of SC and PRC piles. SC and PRC piles are the kind of prefabricated piles.

First, to improve the ductility of SC and PRC piles, the void of these filled with normal strength concrete. Furthermore, PRC piles were improved the details shown in the Fig.2

Then, the result of the experiment is shown. The parameter of the experiment is that the infilled concrete exist or do not. In case of having infilled concrete, either pile were improved ductility under the reverse cyclic loading and constant axial loading, because compression fracture of pile concrete were prevented. Conversely, piles having the void were caused brittle fracture. After brittle fracture, SC pile was able to resist axial force. On the other hand, PRC pile was unable to resist it.

The next chapter has shown the evaluation method of the restoring force model for SC and PRC piles.

First, Flexural capacity of those piles are calculated by fiber model analysis. The difference of having infilled concrete or nothing were described by the stress-strain relationship of the concrete. Deformation performance of those piles is calculated by the total of Bending deformation, Shear deformation and Rotational deformation of pile head connection. Bending deformation is calculated by integration of pile curvature. Shear deformation is calculated assuming the elastic body. Calculation method for Rotational deformation is different by pile head connection type. In case of pile head connection with anchorage bars, Rotational deformation is calculated by integration of anchorage bar strain assuming the triangular distribution. Alternatively, in case of pile head connection embedding footing, Rotational deformation is calculated by equation (11) assuming that fixing ratio is 0.9 .

Then, examination result about relationship between shear force and drift angle were simulated by the suggestion method of restoring force model. The subject of the simulation were five SC piles, two improved PRC piles and twelve conventional PRC piles. As a result, suggestion method using fiber model analysis were able to evaluate the relationship between shear force and drift angle in each pile type. 